\title{
Characterization of humic acids derived from rabbit manure treated by composting-vermicomposting process
}

\author{
P. Campitelli ${ }^{1}$, M. Velasco ${ }^{1}$, S. Ceppi ${ }^{1 *}$ \\ ${ }^{1}$ Departamento de Recursos Naturales, Facultad de Ciencias Agropecuarias, Universidad Nacional de Córdoba, \\ CC 509 -5000 Córdoba, Argentina. *Corresponding author: "Silvia Ceppi: sceppi@agro.unc.edu.ar
}

\begin{abstract}
The aim of this work was to evaluate, through different analytical techniques, the evolution of some chemical and physicochemical properties of humic acid (HA)-like fraction extracted from an organic amendment, like rabbit manure, handle with composting followed by vermicomposting process, in comparison with soil HA, in order to reach an appropriate criterion to evaluate the maturity of an organic amendment.

The raw material used was rabbit manure treated with composting followed by vermicomposting process. Soil and organic amendments were analyzed by chemical properties. The HA was extracted from the amendments samples and from an Entic Haplustol and analyzed the chemical and physicochemical characteristics by several analytical methods.

Through these analytical techniques was possible to follow the evolution of the HAlike fraction during this stabilization-maturation process

Through the composting followed by vermicomposting process the HA-like fraction are evolving toward more stable and complex macromolecule resembling native soil HA.
\end{abstract}

Keywords: organic matter, humic acids, capillary zone electrophoresis, elemental analysis. 


\section{Introduction}

Animal wastes present health and environmental risks and should be treated accurately. Therefore, the need for more environmental sound methods for the treatment and utilization of animal manure has become imperative (Ko et al., 2008).

Composting and vermicomposting cannot be considered as new technologies, but these processes lead to a final stabilized product which can be used to improve and maintain soil quality and fertility (Larney and Hao, 2007; Lazcano et al., 2008; Caricasole et al., 2011)

The use of compost and/or vermicompost is an economical solution for several agricultural and environmental problems and their application is an acceptable way to improve soil fertility and plant growth (Larchevêque et al., 2006; Loffredo et al., 2008, Loffredo and Senesi, 2009)

Composting involves the accelerated degradation of organic matter by microorganisms under controlled conditions, in which the organic material undergoes a characteristic thermophilic stage that allows sanitization of the waste by the elimination of pathogenic microorganisms.

Vermicomposting involves the bio-oxidation and stabilization of organic material by the joint action of earthworms and microorganisms. The combination of composting and vermicomposting has recently been considered as a way of achieving stabilized substrates. Composting enables sanitization of the waste and elimination of toxic compounds, and the subsequent vermicomposting reduce particle size and increases nutrient availability (Lazcano et al., 2008).

The success in compost and/or vermicompost application is based on the use of reliable criteria for testing compost stability and maturity. Soil application of an unstable organic amendment can harm plant, by the phytotoxic compound production, defi- ciency of nitrogen and oxygen concentration, thus the plant yield would be reduced (Senesi et al., 2007). A number of criteria and parameters have been proposed and used as guidelines to test the evolution and modification occurring during the composting and/or vermicomposting process and to evaluate the stability and maturity in the end-product (Smidt and Tintner, 2007; Sellami et al., 2008; Ponsá et al.,2010; Pognani et al., 2010; Xiaowei Li et al., 2011). Several indices are essential for assessing the end-product condition; these include colour, odours, temperature, respirometric test, $\mathrm{C} / \mathrm{N}$, inorganic nitrogen, cation exchange capacity (CEC), germination index (GI). Other parameters like: moisture content, total organic carbon (TOC), humic-like substances $\left(\mathrm{C}_{\mathrm{HS}}, \mathrm{C}_{\mathrm{HA}}, \mathrm{C}_{\mathrm{FA}}\right)$, total nitrogen content $(\mathrm{TN})$, and different methodology, have also been used to determine the state of stability and/or maturity of these materials (Lasaridi et al., 2006; Lhadi et al., 2006; Smidt and Tinter 2007; Campitelli and Ceppi 2008a; Sellami et al., 2008; Xiaowei Li et al., 2011; Pognani et al., 2011).

However, the amount and quality of humic like substances (HS) in an organic amendment are considered as important marker of its maturity, a guarantee for a safe impact and successful performance in soil (Xiaowei Li et al., 2011).

Due to the beneficial properties that would produce the HA-like fraction, the most stable fraction of the HS, their characteristics are suggested as a quality parameter (Smidt and Tinter 2007; Senesi et al., 2007). Therefore, a better understanding of the structures evolution of HS is necessary in order to comprehend the natural process occurring along the maturation process (Fuentes et al., 2006; Romero et al., 2007).

Some methodologies and techniques are proposed to study HA-like fraction of the organic amendments. 
The results of these studies have shown that the HAlike fraction extracted from the organic amendments differ from native soil HA.

Some of these methodologies and techniques are: elemental and functional group analyses, spectroscopic measurements such as UV-Vis, FTIR and ${ }^{13} \mathrm{CNMR}$, capillary zone electrophoresis (CZE), potentiometrics titrations, thermal analyses, fluorescence spectroscopy, among others, (Velasco et al., 2004; Pietro and Castaldi 2004; Peuravuori et al., 2004; Ceppi et al., 2005; Lguirati et al., 2005; Peuravuori et al., 2005; Campitelli et al., 2006; Lhadi et al., 2006; Grube et al., 2006; Senesi et al., 2007; Sen and Chandra 2007; Smidt and Tinter 2007; Plaza et al., 2008; Sellami et al., 2008; Campitelli and Ceppi 2008a; Fernandez et al., 2008; Vanifatova et al., 2008; Xiaowei Li et al., 2011; d'Orlyé and Reiller 2012).

During the maturation process, is possible to consider that the humification takes place in the stabilized organic matter (OM), and thus, the HAlike fraction suffers changes in their fraction suffers changes in their chemical and physicochemical properties chemical, physicochemical properties.

Therefore, one of the most appropriate and reliable criteria to evaluate maturity of any organic amendment should be based on the analysis of chemical and physicochemical properties of HS-like components, i.e. humic acids (HA)-like and fulvic acids (FA)-like fraction in the organic amendment, in comparison with the properties of native soil HA and FA (Senesi et al 2007; Droussi et al., 2009).

The aim of this study was to evaluate, through different analytical techniques, the evolution of some chemical and physicochemical properties of HA-like fraction extracted from an organic amendment, like rabbit manure, handle with composting followed by vermicomposting process in comparison with soil $\mathrm{HA}$, in order to reach an appropriate criterion to evaluate the maturity of an organic amendment.

\section{Material and methods}

\subsection{Soil and organic amendments analyses}

The soil used to extract HA is classified as Entic Haplustol (USDA classification) located in the Province of Cordoba, Argentina.

The raw material used was rabbit manure treated with composting followed by vermicomposting process. During the composting process the thermophilic phase took place for 30 days, the process was carried out for 60 days more (maturation phase), (90 days was the final age for the composting process). The outdoor pile was turned every 15 days during the composting process in order to improve the $\mathrm{O}_{2}$ level inside the pile. Pile moisture was controlled weekly by adding enough water to obtain moisture content not less than $50 \%$ in composting phase. Then, the pile was spread out in ground beds $(1 \mathrm{~m} \times 10 \mathrm{~m})$ and inoculated on the first $15-20 \mathrm{~cm}$ depth with about $500 \mathrm{~g} \mathrm{~m}^{-2}$ earthworms (Eisenia foetida). The vermicomposting process was carried out for 120 days more (total time for composting followed by vermicomposting process was 210 days). During the vermicomposting process, the pile moisture was controlled weekly by adding enough water to obtain moisture content not less than $70 \%$.

The samples were collected during the composting process, at two different times: 30 days at the thermophilic phase (named TRM) and 90 days (named CRM). At each time 10 sub samples were taken at $25 \mathrm{~cm}$ depth in the pile and then mixed to obtain the composite sample. At the end of the vermicomposting process (210 days named VRM) 10 sub samples were collected at $25 \mathrm{~cm}$ depth in the worm bed, and then mixed to obtain the composite sample.

Soil and each organic amendment (TRM, CRM, and VRM) composite samples were air-dried, crushed and passed through a $2 \mathrm{~mm}$ sieves before all the analytical analysis. 
Soil and organic amendments were analyzed for $\mathrm{pH}$ at a rate 1:2.5 (w:v) and 1:5 (w:v) respectively. Total Organic Carbon (TOC) was analyzed by combustion at $540{ }^{\circ} \mathrm{C}$ for $4 \mathrm{~h}$ (Abad, et al., 2002). Total nitrogen content (TN) in soil, and organic amendments were obtained by the Kjeldahl method. The carbon content of humic substances $\left(\mathrm{C}_{\mathrm{HS}}\right)$, humic acids $\left(\mathrm{C}_{\mathrm{HA}}\right)$ and fulvic acids $\left(\mathrm{C}_{\mathrm{FA}}\right)$ were determined according to the technique proposed by Syms and Haby (1971). The carbon content of each fraction $\left(\mathrm{C}_{\mathrm{HS}}, \mathrm{C}_{\mathrm{HA}}\right.$ and $\left.\mathrm{C}_{\mathrm{FA}}\right)$ were calculated as percentage of the TOC, therefore, the $\% \mathrm{C}_{\mathrm{HA}}$ correspond to the Humification index (HI) (Roletto et al., 1985).

\subsection{Humic Acids isolation}

HA from the organic amendments and soil were extracted with $\mathrm{NaOH} 0.1 \mathrm{~mol} \mathrm{~L}^{-1}$, purified with $\mathrm{HCl}: \mathrm{HF}$ (1:3) and dried at low temperature until constant weight, according to the procedure recommended by Chen et al. (1978).

The HA samples used in this work were:

- HA extracted from an Entic Haplustol of Province of Cordoba, Argentina. Denoted as: HA-S. - HA extracted from rabbit manure at the thermophilic phase of the process. Denoted as: HA-TRM. - HA extracted from composted manure. Denoted as: HA-CRM.- HA extracted from vermicomposted manure. Denoted as: HA-VRM.

All solutions were prepared with tridistilled water and all the reagents were ACS reagent grade.

\subsection{Humic Acids analyses}

$\mathrm{HA}$ ash content was measured by heating it at $550{ }^{\circ} \mathrm{C}$ for $24 \mathrm{~h}$. The elemental composition for $\mathrm{C}, \mathrm{H}, \mathrm{N}, \mathrm{S}$ was determined by an analyzer instrument Carlo Erba 1108 , using isothiourea as standard. Oxygen was cal- culated by difference: $\mathrm{O} \%=100-(\mathrm{C}+\mathrm{H}+\mathrm{N}+\mathrm{S}) \%($ ash and moisture-free basis).

To obtain the E4/E6 ratio, the absorbance at $465 \mathrm{~nm}$ and $665 \mathrm{~nm}$ was measured using Spectronic $20 \mathrm{Ge}-$ nesys Spectrophotometer on solution containing 3.0 $\mathrm{mg}$ of each HA in $10 \mathrm{~mL}$ of $0.05 \mathrm{~mol} \mathrm{~L}^{-1} \mathrm{NaHCO}_{3}$. The ratios of absorbance at $465 \mathrm{~nm}$ and $665 \mathrm{~nm}$ gave the E4/E6 ratio (Kononova, 1982).

\subsection{Potentiometric titration}

Potentiometric titrations were carried out according to the technique proposed by Campitelli et al. (2003), which is briefly: HA solution of each samples were prepared by dissolving HA $(\approx 50 \mathrm{mg})$ with minimum volume of $\mathrm{NaOH}$ solution $\left(0.1 \mathrm{~mol} \mathrm{~L}^{1.1}\right)$ and adding water up to the final volume $(50 \mathrm{~mL})$. An aliquot containing the desired amount of HA $(\approx 7-8 \mathrm{mg})$ was transferred to the titration flask containing $10 \mathrm{~mL}$ of tridistilled water. The titrant $\left(\mathrm{HCl}=0.05 \mathrm{~mol} \mathrm{~L}^{-1}\right)$ was added from an automatic burette (Schott Geräte $\mathrm{T} 80 / 20$ ) at a titrant rate of $0.1 \mathrm{ml} / 40 \mathrm{~s}$. This rate was chosen taking into consideration that the variation of $\mathrm{pH}$ values should range between 0.02 and $0.04 \mathrm{pH}$ units. The $\mathrm{pH}$ values were measured with an Orion Research $901 \mathrm{pH}$ meter equipped with a glass-combined electrode (Orion 9103 BN). All titrations were performed in $\mathrm{KCl} 0.01 \mathrm{~mol} \mathrm{~L}^{-1}$ as background electrolyte. The same titration was followed in absence of HA (reference or blank titration) for each titration curve, in order to subtracts it from the raw data titration, and thus obtain the charge developed by the HA sample. Each HA solution, with the corresponding blank solution, was titrated by triplicate and the reported data representing the average values. All the reagents were ACS reagent grade. 


\subsection{Capillary zone electrophoresis}

Capillary zone electrophoresis (CZE) experiments were performed on an Agilent Technology Capillary electrophoresis system equipped with a diode array. Operation of the instrument, data collection and analysis were controlled by Agilent ChemStation software. The polarity was negative, voltage of $-10 \mathrm{kV}$, temperature $25^{\circ} \mathrm{C}$, total run time $20 \mathrm{~min}$ (for time migration higher than 20 min no significant peak were observed). Samples were injected hydrodynamically using pressure of $5000 \mathrm{~Pa}$ for $60 \mathrm{~s}$. The absorbance was monitored at three different wavelengths $(243 \mathrm{~nm}, 214 \mathrm{~nm}$ and $260 \mathrm{~nm}$ ) and $243 \mathrm{~nm}$ was selected to report.

Each HA electropherogram was carried out by triplicate and the reported data representing the average values.

The dimensions of the fused-silica capillary were $75 \mu \mathrm{m}$ internal diameter; $81.7 \mathrm{~cm}$ total length and $73.2 \mathrm{~cm}$ effective length.

All the solutions and background electrolyte (BGE) were prepared from analytical (p.a. or HPLC) chemicals and ultra pure water.

BGE was buffer borate $20 \mathrm{mmol} \mathrm{L}^{-1}$ at $\mathrm{pH}=9.3$, the concentration of the HA solutions were $1000 \mathrm{ppm}$.

At the beginning of daily work, the capillary was washed for 5 min with $0.1 \mathrm{~mol} \mathrm{~L}^{-1} \mathrm{NaOH}$ solution, followed by $5 \mathrm{~min}$ washing with ultra pure water and 20 min with $\mathrm{BGE}$ at $25^{\circ} \mathrm{C}$ and $10^{4} \mathrm{~Pa}$. At the end of the daily work, the capillary was rinsed with BGE for $5 \mathrm{~min}$ and water for $10 \mathrm{~min}$, at the same temperature and pressure condition.

The capillary was treated before each sampling injection, as following, pre-condition: 2 min with $\mathrm{NaOH} 0.1 \mathrm{~mol} \mathrm{~L}^{-1}$ at $10^{4} \mathrm{~Pa}$, followed by washing with BGE for $3 \mathrm{~min}$ at $10^{4} \mathrm{~Pa}$, and finally waiting for
1 min. Post-run conditions were: 1 min with $\mathrm{NaOH}$ $0.1 \mathrm{~mol} \mathrm{~L}^{-1}$ at $10^{4} \mathrm{~Pa}$, followed by $5 \mathrm{~min}$ with water at the same pressure.

\section{Results and discussion}

\subsection{Chemical properties and humification parameters}

The $\mathrm{pH}$ value was similar for TRM and CRM. At the end of the vermicomposting process (VRM), the $\mathrm{pH}$ value significantly decrease; probably due to the mineralization of $\mathrm{N}$ and $\mathrm{P}$ compounds, the release of $\mathrm{CO}_{2}$ and the presence of organic acids from microbial metabolism (Kaushik and Garg, 2004; Lazcano et al., 2008; Xiaowei Li et al., 2011). Total organic carbon (TOC) and total nitrogen (TN) in the sample at thermophilic phase (TRM) was high, however, both contents decreased after the vermicomposting process (Table 1). The decreasing in TOC was about $35 \%$ between the thermophilic phase and the composting process and during the vermicomposting process the loss of TOC was lower $(\sim 6 \%)$. Labile organic compounds, such as simple carbohydrates, fats and amino acids, are degraded in the first stages of the process; cellulose, hemicelulose, lignin and other resistant substrates, take longer time for their degradation and transformation (Bernal et al., 2009). The decreasing of TN was about $28 \%$ at the end of the composting process (90 days). This behaviour indicates the occurrence of a net organic matter mineralization, volatilization of ammonia $\mathrm{N}$ and/or lixiviation. The TN content in VRM was practically the same than in CRM, which indicate that in this period (vermicomposting) the content of $\mathrm{N}$ compounds was degraded at lower rate than in the 
former phase of the process (composting) or probably the $\mathrm{N}$ contribution from the biological activity (urine and feces) of the earthworms could balance the lost trigged by the degradation (Gajalakshmi et al., 2005). The decreasing in $\mathrm{C} / \mathrm{N}$ ratio (Table
1) during the composting process and the slightly variation in the vermicomposting phase indicate the development of the raw material towards a maturity state, suggested also through the increasing in the \% $\mathrm{C}_{\mathrm{HS}}$ content (Table 1)

Table 1: Chemical characteristics of soil and organic amendments at the different time of the process.

\begin{tabular}{ccccccccc}
\hline Samples & $\mathbf{p H}$ & $\mathbf{T O C}$ & $\mathbf{T N}$ & $\mathbf{\% C}_{\mathbf{H S}}{ }^{*}$ & $\mathbf{\% C}_{\mathbf{H A}}{ }^{*}$ & $\mathbf{\% C}_{\mathbf{F A}}{ }^{*}$ & $\mathbf{C}_{\mathbf{H A}} / \mathbf{C}_{\mathbf{F A}}$ & $\mathbf{C} / \mathbf{N}$ \\
\hline Soil & 6.40 & 28.4 & 2.0 & 35.9 & 17.9 & 18.0 & 0.9 & 14.2 \\
TRM & $9.23 \mathrm{a}$ & $620.5 \mathrm{a}$ & $20.6 \mathrm{a}$ & $3.05 \mathrm{a}$ & $5.80 \mathrm{~b}$ & $7.25 \mathrm{~b}$ & $0.8 \mathrm{a}$ & $30.1 \mathrm{a}$ \\
CRM & $9.15 \mathrm{a}$ & $403.7 \mathrm{~b}$ & $14.9 \mathrm{~b}$ & $4.02 \mathrm{~b}$ & $6.69 \mathrm{c}$ & $3.72 \mathrm{a}$ & $1.8 \mathrm{c}$ & $27.0 \mathrm{~b}$ \\
VRM & $8.51 \mathrm{~b}$ & $379.7 \mathrm{c}$ & $14.2 \mathrm{~b}$ & $7.64 \mathrm{c}$ & $4.78 \mathrm{a}$ & $3.16 \mathrm{a}$ & $1.5 \mathrm{~b}$ & $26.7 \mathrm{~b}$ \\
\hline
\end{tabular}

${ }^{*} \% \mathrm{C}_{\mathrm{HS}}, \mathrm{C}_{\mathrm{HA}}, \mathrm{C}_{\mathrm{FA}}$ are calculated as function of TOC. TOC, TN $\left(\mathrm{g} \mathrm{kg}^{-1}\right)$ Different letters (a-c), for organic amendments, in the same column indicate significant differences $(P<0.05)$ according to Tukey test (For the statistical estimation the soil was not take into consideration).

The humification parameter, the $\% \mathrm{C}_{\mathrm{HS}}$, slightly increase during the composting phase (90 days), and through the vermicomposting period the $\mathrm{C}_{\mathrm{HS}}$ content is about $50 \%$ greater than in composted material (CRM). This behaviour could be due since the vermicomposting led to homogeneous degradation of all types of $\mathrm{C}$ compounds, with no selective accumulation of any preferential form, and thus increase the total extractable organic $\mathrm{C}$ in alkaline solution (Sen and Chandra 2007; Plaza et al., 2008).

The $\% \mathrm{C}_{\mathrm{HA}}$ (humification index) increase in the first phase of the process (90 days) followed by a noticeable decrease $(\sim 28 \%)$ at the end of the vermicomposting period (Table 1). This behaviour reflects, probably, a reduction of aromatic structures, suggesting that in the final product of this vermicomposting process the organic compounds are more degradable, probably with a greater content of aliphatic structures than in the compost end-product. It seems that the earthworm produces a final product with some homogeneity between both fraction content $\left(\mathrm{C}_{\mathrm{HA}}\right.$ and $\mathrm{C}_{\mathrm{FA}}$ ) (Table 1) (Sen and Chandra 2007; Sellami et al., 2008). The decreasing in this fraction $\left(\% \mathrm{C}_{\mathrm{HA}}\right)$ could be produced, also, for the lixiviation of some hydrosolubles organic compound due to the high moisture content during this phase of the total process

$\mathrm{C}_{\mathrm{FA}}$ content (Table 1) shows a continuous decrease throughout the complete time of the process ( 210 days), this can be explained taking into account the nature of this fraction (FA), which contain easily degradable compound such as polysaccharides which were exposed first to microbial attack (Sellami et al., 2007; Plaza et al., 2008; Xiaowei Li et al., 2011). The final stages of vermicomposting process would involve several changes and transformation in the chemical structure of the organic matter.

The ratio $\mathrm{C}_{\mathrm{HA}} / \mathrm{C}_{\mathrm{FA}}$ (Table 1), also known as "degree of polymerization or polymerization index", increase during the composting process (90 days), reflecting the formation of complex molecules $\left(\mathrm{C}_{\mathrm{HA}}\right)$ from simpler one $\left(\mathrm{C}_{\mathrm{FA}}\right)$ and the occurrence of synthesis of organic compounds resistant to microbial degradation (Plaza et al., 2008). Roletto et al. (1985) used the ratio of $\mathrm{C}_{\mathrm{HA}} /$ $\mathrm{C}_{\mathrm{FA}}$ to establish the humification level of the $\mathrm{OM}$ of compost from different origins, including manure, indicating a value greater than 1 for a good humification 
degree. However, Senesi (1989) and Iglesias-Gimenez and Perez-Garcia (1992) have suggested that a ratio $\mathrm{C}_{\mathrm{HA}} / \mathrm{C}_{\mathrm{FA}}$ greater than 1.6 indicate a good maturity degree achieved by the organic matter.

The ratio $\left(\mathrm{C}_{\mathrm{HA}} / \mathrm{C}_{\mathrm{FA}}\right)$ slightly decreases during the vermicomposting time, reaching a value of 1.5 , suggesting a roughly reduction in the contents of molecules with a high degree of condensation and humification, which could indicate that the earthworm activities led to a homogeny degradation of all types of C compounds without selectivity, however, maturity level reached do not decrease.
Earthworms are known to digest long chains of polysaccharides, enhancing microbial colonization and thus, changing the structure of the raw material. This behaviour suggests an increase in the total aliphatic $\mathrm{C}$ and polysaccharides at the end of vermicomposting suggesting neosynthesis in the vermicompost (Sen and Chandra 2007).

\subsection{Elemental composition of HA-like}

The elemental analysis, $\mathrm{H} / \mathrm{C}, \mathrm{N} / \mathrm{C}, \mathrm{O} / \mathrm{C}$, ash content and E4/E6 ratio are shown in Table 2.

Table 2: Elemental composition (ash and moisture-free basis), H/C, N/C, O/C (atomic ratios) and E4/E6 ratio of the HA studied.

\begin{tabular}{ccccccccccc}
\hline Humic acids & $\mathbf{C}(\%)$ & $\mathbf{H}(\%)$ & $\mathbf{N}(\%)$ & $\mathbf{S}(\%)$ & $\mathbf{O}(\%)$ & $\mathbf{H} / \mathbf{C}$ & $\mathbf{N} / \mathbf{C}$ & $\mathbf{O} / \mathbf{C}$ & Ash(\%) & E4/E6 \\
\hline $\boldsymbol{H} \boldsymbol{A}-\boldsymbol{S}$ & 54.6 & 3.3 & 2.8 & $\mathrm{a}$ & 39.3 & 0.73 & 0.044 & 0.54 & 1.7 & 4.3 \\
$\boldsymbol{H} \boldsymbol{A}-\boldsymbol{T R M}$ & 59.5 & 6.9 & 5.6 & 1.4 & 26.6 & 1.39 & 0.081 & 0.33 & 14.1 & 5.2 \\
$\boldsymbol{H} \boldsymbol{A}-\boldsymbol{C R M}$ & 54.2 & 5.8 & 6.1 & 1.7 & 32.2 & 1.28 & 0.095 & 0.45 & 12.0 & 5.8 \\
$\boldsymbol{H} \boldsymbol{A}-\boldsymbol{V} \boldsymbol{R} \boldsymbol{M}$ & 50.1 & 5.5 & 5.8 & 1.7 & 36.9 & 1.31 & 0.098 & 0.55 & 11.3 & 5.7 \\
\hline
\end{tabular}

a: $\mathrm{S}$ content $(<0.3 \%)$ detected but not quantified.

The HA-like fraction isolated throughout the process (composting followed by vermicomposting) presents $\mathrm{C}$ and $\mathrm{O}$ content similar to those HA extracted from cattle manures before and after vermicomposting by Plaza et al. (2008).

The HA-like fraction extracted from composted and/or vermicomposted materials usually shown a decrease in $\mathrm{C}$ content and an increase in the oxygen content through the process (Xiaowei et al., 2011); whereas, in general, the content of $\mathrm{N}, \mathrm{H}$ and $\mathrm{S}$ are higher with respect to the soil HA (Senesi and Brunetti 1996). The atomic ratio of $\mathrm{O} / \mathrm{C}, \mathrm{H} / \mathrm{C}$ and N/C are often used to monitor structural changes of humic substances (Adani et al., 2006). The increase in the $\mathrm{O} / \mathrm{C}$ ratio indicates that an oxidation process take place through the composting and vermicomposting period.
The HA extracted after the composting phase (HA$\mathrm{CRM}$ ) shows a decrease of the ratio $\mathrm{H} / \mathrm{C}$ in comparison with HA-TRM, probably due to a loss of aliphatic chains, initially present in HA-TRM. The atomic ratio $\mathrm{H} / \mathrm{C}$ for $\mathrm{HA}$ extracted after the vermicomposting process (HA-VRM) presents a slight increase with respect to the HA-CRM, indicating less condensed or less substituted aromatics rings than HA-CRM (Chai et al., 2007; Plaza et al., 2008). HA extracted from all organics amendments analyzed (HA-TRM; HA-CRM; HA-VRM) have $\mathrm{H} / \mathrm{C}$ ratio higher than that observed for HA-S, suggesting that the humification period is not complete.

$\mathrm{N} / \mathrm{C}$ ratio in all HA studied are greater than the value for HA-S, probably due to the incorporation of $\mathrm{N}$-compounds present in rabbit manure, like proteina- 
ceous materials, polysaccharides and compounds not degraded during both process. (Lguirati et al., 2005; Droussi et al., 2009).

The scattering of monochromatic light in a diluted solution of macromolecules or colloidal particles is closely related to weight, size and interaction of particles in solution, the value of the quotient, E4/ E6, suggest the aggregation level, with higher values indicating a more aggregated humic macromolecule (Chen et al., 1977; Pertusatti and Prado, 2007). E4/ E6 ratio provide interesting information if it is used to compare data of humic acids extracted from the same matrix, like a manure handle with a sequence of treatments (composting followed by vermicomposting). (Adani et al., 2006).

The HA extracted from the organic amendments analyzed have E4/E6 ratio higher than the HA-S (Table 2), indicating a more aggregated humic macromolecule, a greater aliphatic character, less molecular condensation and therefore an incomplete humification degree (Pertusatti and Prado, 2007). The HA-CRM and HA-VRM E4/E6 values are similar, suggesting that after the vermicomposting process the structural characteristic of the macromolecules do not change substantially from this point of view.

\subsection{Acid base properties}

The charges-pH curves (-Q versus $\mathrm{pH}$ ) of the HA isolated, between $\mathrm{pH} 3$ and 11, obtained from potentiometric titration, corrected for blank solution and fitted with sixth degree polynomial according to Machesky (1993) and Campitelli and Ceppi (2008b), are shown in the Figure 1a. This smoothing function was selected for their simplicity

The charge development of HA isolated from the different ages of the organic amendment (HA-TRM, HA-CRM and HA-VRM) are lower than that of HA-S and increase with process time.
The greater change was observed into the first 90 days of the process (from HA-TRM to HA-CRM). According to the methodology proposed by Ritchie and Perdue (2003), at $\mathrm{pH} \mathrm{8,} \mathrm{all} \mathrm{carboxylic} \mathrm{groups}$ are titrated. At this $\mathrm{pH}$ value, the charge is greater in HA-CRM $(\approx 70 \%)$ than in HA-TRM. The HA-VRM charge development increase $(\approx 20 \%)$ in comparison with HA-CRM at $\mathrm{pH}=8$. Therefore, these charged sites (carboxylic group) present in the macromolecule, increase in the following order: HA-TRM $<$ HA$\mathrm{CRM}<\mathrm{HA}-\mathrm{VRM}$. In the range between $\mathrm{pH}$ 8-10 Ritchie and Perdeu (2003) considered that a half of the phenolic groups are titrated. The change in the charge development in this range of $\mathrm{pH}$, for the HA analyzed, was similar to that observed for the former acidic groups. In general, the total acidity increase about 70 $80 \%$ during the composting period and about $20-25 \%$ in the vermicomposting phase. This tendency indicate that during this period of the process (first 90 days) occur the principal changes in this physicochemical property in the HA macromolecule, and suggest that during the composting phase take place the most important oxidative process. During the vermicomposting period, the HA-VRM charge development increases about $20-25 \%$, indicating different pathway in the stabilization-maturation process of the organic matter. This behaviour suggest that the HA-like fraction is under a less oxidative stage in which an homogeneous degradation of $\mathrm{C}$ compounds or a neosynthesis of polysaccharides could take place (Sen and Chandra 2007; Plaza et al., 2008; Lazcano et al., 2008).

Through the first derivative of the $-\mathrm{Q}$ versus $\mathrm{pH}$ curves $(-\mathrm{dQ} / \mathrm{dpH})$ obtained from the titration curves smoothed with the polynomial equation (Figure 1b), is possible: i) to obtain the apparent proton-dissociation constant (Pkaap), ii) to analyze the chemical heterogeneity of each class of acidic group present in the HA macromolecule, iii) to estimate the concentration of each set of acidic groups by calculation the area 
under each peak and iv) to estimate the buffer capacity developed by each class of acidic site (Nederlof et al., 1994; Koopal et al., 2005; Campitelli et al., 2006; Campitelli et al., 2008b). In this way, is possible to follow the acid-base characteristics evolution for the principal acidic groups (carboxylic and phenolic) in comparison with those of HA-S.

The number of site classes is then equal to the number of peaks and the peak position could be used as an average of the apparent dissociation constant (pKaap).
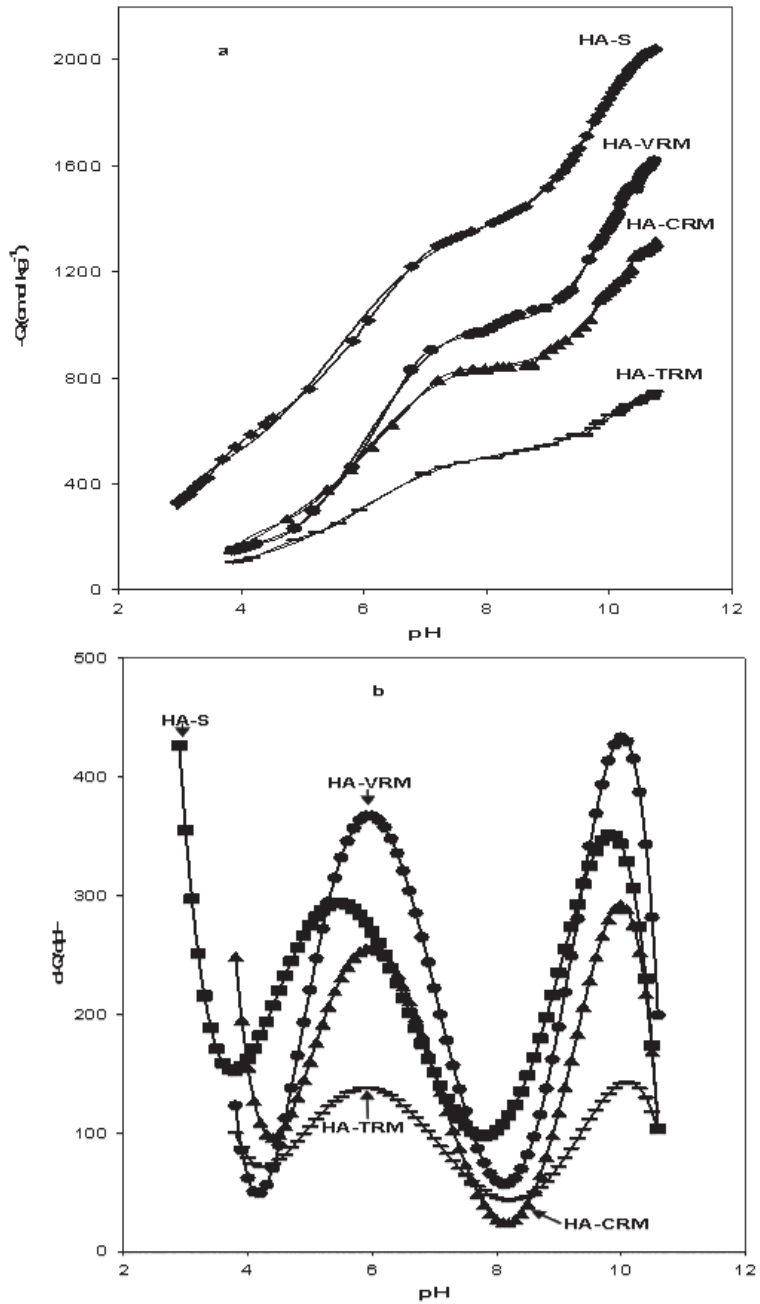

a: Charge-pH curves of humic acids extracted from rabbit manure at thermophilic phase (HA-TRM) treated with composting (HA-CRM) followed by vermicomposting process (HA-VRM) and soil (HA-S). The solid lines were calculated on the basis of the sixth polynomial equation (with $\mathrm{R}^{2}$ values exceeding 0.999 in all cases). (Charge development were calculated taking into account the ash content)

b: Apparent proton-affinity distribution of humic acids extracted from rabbit manure at thermophilic phase (HATRM) treated with composting (HA-CRM) followed by vermicomposting process (HA-VRM) and soil (HA-S) obtained from the first derivatives through charge- $\mathrm{pH}$ curves $[\mathrm{d}(-\mathrm{Q}) / \mathrm{d}(\mathrm{pH})]$ smoothing with sixth degree polynomial equation through the experimental data in the range of $3-10$. 
The samples of HA analyzed show two main peaks, the first would be assigned to the carboxylic groups or sites (strong acidic sites) and the second to the phenolic groups (weak acidic sites). The HA showed, also, a small or developing peaks at more acidic $\mathrm{pH}$ values $(\leq 4)$, indicating, probably, a presence of stronger acidic sites.

HA-TRM presents two broad peaks, which have maxima at $\mathrm{pH} 5.9$ and $\mathrm{pH} 10.1$ respectively; the first corresponds to strong acid sites (carboxylic groups) and the second to weak acidic sites (phenolic groups). The widths of both peaks are large, indicating that in this phase of the process (30 days) the HA-like fraction is characterized by a large number of acidic sites with similar dissociation properties, and have certain overlapping between the both peaks (i.e. strong and weak acidic sites). In this way, is possible to assume that the HA have a large chemical heterogeneity or are a complex mixture of organic compounds produced during the original material decomposition. The concentration of each acidic sites and therefore, their buffer capacity contribution (height of the peaks), would be very low if the organic amendment is used at this time of the process.

The HA-CRM, present the peaks positions at $\mathrm{pH}$ 6 and 10, corresponding to strong and weak acidic site, respectively. Both maxima are higher and narrower than those observed for HA-TRM, indicating that the content of both acidic site increases significantly through this period of the process ( 90 days) and have a lower chemical heterogeneity and more diffe- rentiation between both classes of acidic sites. This behaviour could suggest that the organic amendment at the thermophilic stage (TRM) progress towards a relatively stable humus like end-product through a bio-oxidative, mineralization and humification processes in which the unstable organic matter is partially transformed through decomposition, resyntesis and polymerization reactions.

The strength of the carboxylic groups is practically the same as the HA-TRM but the buffer capacity increases about twofold in comparison with HA-TRM.

The peak positions of both peaks for HA-VMR (6 and 10 respectively) are similar than the other amendments HA analyzed indicating that the acidic strength do not change significantly along the process. The height of the first maximum is about $35 \%$ higher than those observed in HA-CRM; while, the maximum corresponding to weak acidic sites (phenolic groups) increase about 20\%, that is in agreement with that observed by Plaza et al.(2005; 2008) and Xiaowei Li et al., (2011). The acidic sites content (table 3) (carboxylic and phenolic groups) of HA-VRM are close to that corresponding to HA-S, probably because during the vermicomposting period the organic matter reach a condition in which the complex organic compound resemble native soil humic acids (HA-S). The buffer capacity and chemical heterogeneity of HA-VRM are similar to HA-S, indicating that after the vermicomposting process the HA-like fraction of the organic amendment have similar acid-base properties that HA-S. 
Table 3: Acidic functional groups content (carboxylic and phenolic) calculated by integration of the area under each maxima of the curves $(\mathrm{d}-\mathrm{Q} / \mathrm{dpH})$ obtained through the first derivative of smoothed experimental data. pKaap values obtained by Henderson-Hasselbalch equation.

\begin{tabular}{ccccc}
\hline Humic acids & -COOH $\left(\mathbf{c m o l ~} \mathbf{~ k g}^{-1}\right)$ & pKaap* & -OH $\left(\mathbf{c m o l ~ k g}^{-1}\right)$ & pKaap* \\
\hline HA-S & 1033 & 5.19 & 641 & 9.80 \\
HA-TRM & 422 & 5.88 & 231 & 9.97 \\
HA-CRM & 677 & 5.83 & 409 & 10.18 \\
HA-VRM & 886 & 5.86 & 639 & 10.74 \\
\hline
\end{tabular}

$* \mathrm{R}^{2}$ value was 0.99 .

HA isolated from rabbit manure at the thermophilic stage (HA-TRM), after the composting process (HA$\mathrm{CRM}$ ) and after the vermicomposting process (HAVRM) show, for the strong and weak acidic sites (carboxylic and phenolic), pKaap values shifted toward greater values in comparison with HA-S (5.5 and 9.8 respectively), indicating that the acidic sites are slightly weaker than the corresponding groups for HA-S.

At the lowest $\mathrm{pH}$ measured (sites domains below 4), HA-CRM shows a developing peak (Figure 1b), indicating that very acidic sites could be present in the HA-like substances, and their content would be similar to HA-S. HA-TRM and HA-VRM present lower content of these classes of acidic sites, probably because, is the initial phase (thermophilic phase) for HA-TRM, and for HA-VRM may be due to the different biological transformation operated by vermicomposting of the raw material.

In order to verify the pKaap values obtained using the first derivative of the charge vs. $\mathrm{pH}$ curves (d-Q/ $\mathrm{dpH}$ ), the experimental data was fitted to a modified Henderson-Hasselbalch function describing the proton binding by two classes of binding sites, strong acidic site (carboxylic groups) and weak acidic site (phenolic groups). The values obtained (table 3) are similar to those found through the peak position of both maxima obtained by the first derivative of the curve $(\mathrm{d}-\mathrm{Q} / \mathrm{dpH})$, indicating that the principal acidic site classes characterizing the acid-base behaviour of the HA-like fraction of these organic amendments would be assigned to carboxylic and phenolic groups. The acidic site content obtained by the determination of the areas under each peaks of the $\mathrm{d}-\mathrm{Q} / \mathrm{dpH}$ curves are shown in table 3 .

The changes observed in the acid-base properties of the HA analyzed suggest that through the composting followed by vermicomposting process the HAlike substances are transformed to complex organic compound that resembles native soil HA (Benitez et al., 2005; Plaza et al., 2008)

\subsection{Capillary zone electrophoresis}

The principal characteristics of HA-like substances are the occurrence of acidic site with different strength, the principal groups are the strong (carboxilic groups) and weak (phenolic groups) acidic site. For these HA analyzed the average Pkapp value are 
around $5-6$ for the carboxylic groups and $9-10$ for the phenolic groups.

At the experimental condition $(\mathrm{pH} \approx 9)$ almost all acidic groups of HA are deprotonated (negatively charged). The presence of negative charges permit to separate $\mathrm{HA}$ by electrophoresis in electrical field $(+)$ to $(-)$ in which the EOF (electroosmotic flow) is responsible for the movement of the analyte (Peuravouri et al., 2004).

The electropherogram of HA-TRM presents five differentiable peaks with low absorbance at $243 \mathrm{~nm}$ (Figure 2). Between the both first peak (5.6 and 9.7 min respectively) could be distinguish numerous peaks without a correct resolution, indicating the presence of different fractions or compounds, with a low $\mathrm{Q} / \mathrm{m}$ ratio, (polysaccharides, aliphatic fractions, $\mathrm{N}$ compound) having close electrokinetic behaviour which cannot be separated by CZE, The most important peak can be observed at time migration $\approx 10 \mathrm{~min}$ with a shoulder at $\approx 11$ min and a peak with a low absorbance can be observed at $\approx 16 \mathrm{~min}$, indicating the presence of many fractions with different charge/mass ratio and thus, different electrokinetic mobility. This behaviour could be due to the high degree of chemical heterogeneity, due to the short period of stabilization (30 days), which is in agreement with those observed through the $\mathrm{d}-\mathrm{Q} / \mathrm{dpH}$ curve (Figure $1 \mathrm{~b}$ ).
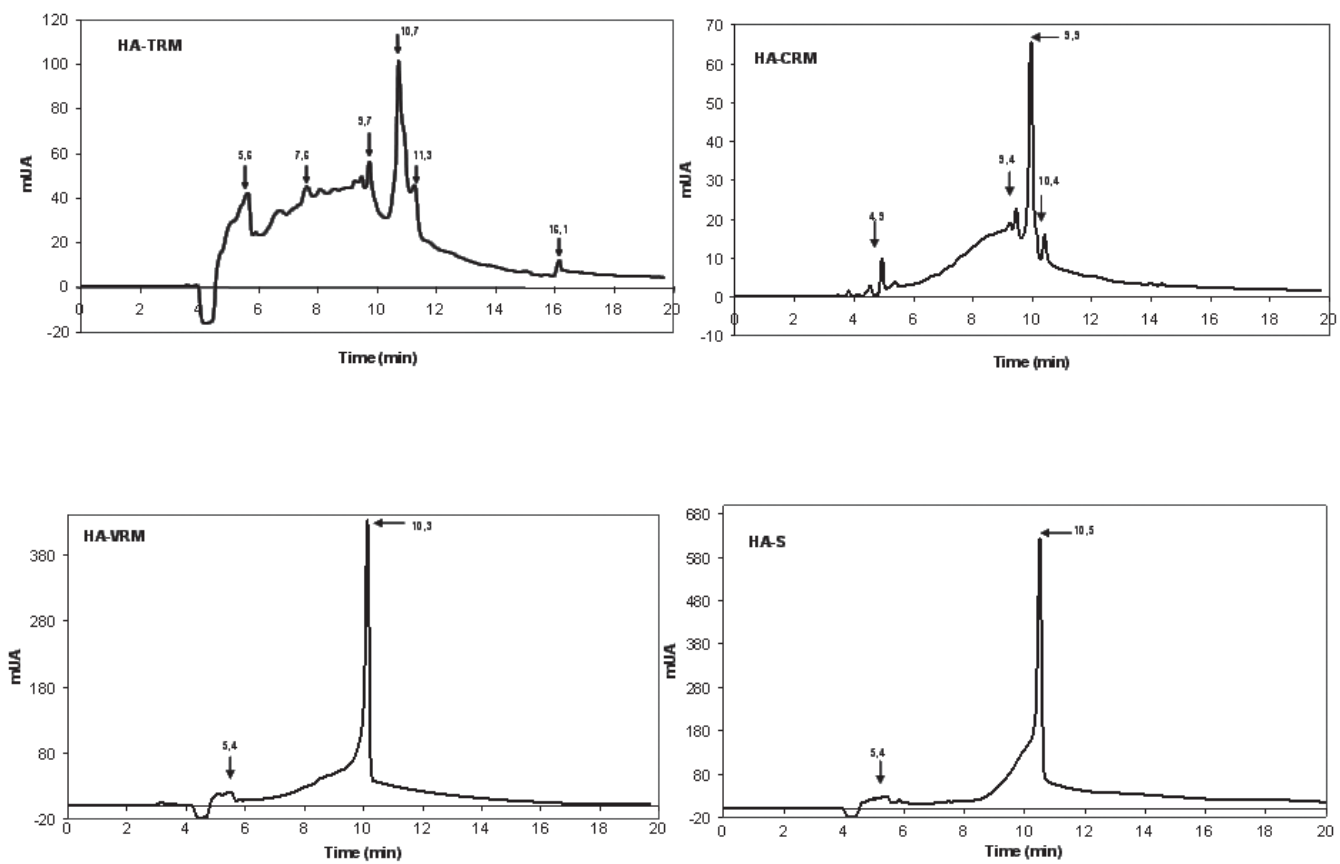

Figure 2: Electropherograms of acids extracted from rabbit manure at thermophilic phase (HA-TRM) treated with composting (HA-CRM) followed by vermicomposting process (HA-VRM) and soil (HA-S) in buffer borate 20mM $(\mathrm{pH}=9.3)$, the concentration of the AH solutions were $1000 \mathrm{ppm}$. CZE conditions: voltage of $-10 \mathrm{kV}$, injection hydrodynamic $5000 \mathrm{~Pa}$ for $60 \mathrm{~s}$, detection at $243 \mathrm{~nm}$, fused-silica capillary, $81.7 \mathrm{~cm}$ total length, $75 \mu \mathrm{m}$ i. d. (effective length $73.2 \mathrm{~cm}$ ). Total run time $20 \mathrm{~min}$ (for time migration higher than $20 \mathrm{~min}$ no significant peak were observed). 
The electropherogram corresponding to HA-CRM presents a better definition than the HA-TRM (Figure 2). The electropherogram pattern (HA-CRM) shows 4 main peaks, with slightly differences in the time migration with respect to the peaks present in the HA-TRM electropherogram, and a broad peak at the time migration range 6-9 min, called usually the "humic hump", which correspond to the average electrophoretic mobility of different compounds or fractions. These changes could indicate a variation in the charge/mass ratio of each compound or fractions, and thus an evolution of the HA-like fraction toward a less chemical heterogeneity, also in agreement with that observed in $\mathrm{d}-\mathrm{Q} / \mathrm{dpH}$ curve (Figure 1b). The HA-CRM electropherogram shown similar profile to other soils HA, in similar experimental condition (He et al., 2010; de Moraes and Rezende 2008), suggesting that at this phase of the process the structural transformation in HA-like fraction were significant to perform the evolution toward similar soil HA characteristics.

HA-VRM shows an electropherogram pattern in which can be observed clearly one peak at a migration time of $10 \mathrm{~min}$, with a smaller absorbance than that observed for HA-S and the width peak is similar to HA-S (Figure 2). This behaviour suggests that, in the raw material used in this stabilization and maturation process, (composting followed by vermicompostig), the HAlike fraction evolves toward a similar structure of HA-S

The width of the principal peak ( $\sim 10 \mathrm{~min})$, decrease as time of process increase, indicating changes in the structure of the macromolecule, toward less chemical heterogeneity, and their absorbance increase as the time of process increase, suggesting that this fraction could be the most representative fraction in the fingerprint of the HA macromolecule. This behaviour could be used as a marker of the humification process, taking place during the stabilization-maturation process.

The smaller absorbance observed in HA-VRM in comparison with the HA-S value; indicate lower con- centration of this fraction in the HA-VRM. These characteristics are in agreement with that shown by the other analytical techniques employed to study these humic acids.

The electropherograms of all HA-like fraction analyzed shown one principal peak at $\approx 10 \mathrm{~min}$, suggesting that this would be a main structure which behaves as sink of the other carbon compounds present in the raw material, and in this way leads the HA-like fraction toward a supramolecular structure similar to HA extracted from natural soil.

The electropherograms revealed the evolution of the AH-like fraction since the raw materials to the final of the process, showing it through the decreasing of the number of fractions with different time migration, indicating that throughout the composting followed by vermicomposting process the HA-like fraction are evolving toward more stable supramolecular structure resembling native soil HA.

\section{Conclusions}

Through these analytical techniques was possible to follow the evolution of the HA-like fraction during this stabilization-maturation process

These techniques, potentiometric titrations and capillary zone electrophoresis (CZE) allow the estimation of the organic amendment maturity through the HA-like fraction characteristics.

The AH charge development, the acidic groups content and thus the buffer capacity, increase as the time of process increase. The acidity strength of both classes of acidic sites in the HA-like fraction of the organic amendments is slightly weaker than the acidic groups of the HA-S. The chemical heterogeneity of the HA like fraction decrease with the time of process.

The electropherograms revealed the evolution of the HA-like fraction during the composting followed by vermicomposting. 
The main and more significant changes and structural transformation of the raw material take place during the composting process and could be analyzed through the evolution of the chemical and physicochemical properties of their HA-like fraction.

Some evaluation criterion of the maturity state of HA-like fraction could be: the increasing in the charge development and buffer capacity, the decreasing in the chemical heterogeneity and the number of fraction with different electrokinetic mobility, i.e. when the HA-like fraction evolves in order to have similar characteristics as soil HA.

\section{Acknowledgements}

SeCyT-UNC are gratefully acknowledged for financial support.

\section{References}

Abad, M., Noguera, P., Puchades, R., Maqueira, A., Noguera, V. 2002 Physico-chemical properties of some coconut coir dusts for use as a peat substitute for containerised ornamental plants. Biores. Technol. 82, 241-245.

Adani, F., Ricca, G., Tambone, F., Genevini, P. 2006 Isolation of the stable fraction (the core) of humic acids. Chemosphere. 65, 1300-1307.

Benitez, E., Sainz, H., Nogales, R., 2005. Hydrolytic enzyme activities of extracted humic substances during the vermicomposting of lignocellulosic olive waste. Biores Technol. 96, 785-790.

Bernal, M.P., Alburquerque, J.A., Moral, R. 2009 Composting of animal manures and chemical criteria for compost maturity assessment. A review Biores.Technol. 100, 5444-5453

Bustamante, M.A., Paredes, C., Marhuenda-Egea, F.C., Pérez-Espinosa, A., Bernal, M.P., Moral, R. 2008 Co-composting of distillery wastes with animal manures: Carbon and nitrogen transformations in the evaluation of compost stability. Chemosphere. 72, 551-557.

Campitelli, P,A., Velasco, M,I., Ceppi, S,B. 2006 Chemical and physicochemical characteristics of humic acids extracted from compost, soil and amended soil. Talanta. 69, 1234-1239.

Campitelli, P., Ceppi, S. 2008a. Chemical, physical and biological compost and vermicompost characterization: A chemometric study. Chemometer Intell.Lab. 90, 64-71.

Campitelli, P., Ceppi, S. 2008b Effects of composting technologies on the chemical and physicochemical properties of humic acids. Geoderma. 144, 325-333.

Campitelli, P., Velasco, M., Ceppi, S. 2003. Charge development and acid-base characteristics of soil and compost humic acids. J of Chil Chem Soc. 48, 3, 91-96.

Caricasole, P., Provenzano, M.R., Hatcher, P.G., Senesi, N. 2011 Evolution of organic matter during composting of different organic waste assessed by CPMAS ${ }^{13} \mathrm{C}$ NMR spectroscopy. Waste Manage. $31,411-415$

Ceppi, S., Velasco, M., Campitelli, P., Peña-Méndez, E., Havel, J. 2005. Characterization of humic acids originated from argentinean compost and soil by capillary electrophoresis and mass spectrometry. J. Chil Chem Soc. 50, 3, 527-533.

Chai, X., Shimaoka, T., Xiaoyan, C., Qiang, G., Youcai, Z. 2007 Specroscopic studies of the progress of humification process in humic substances extracted from refuse in a landfill. Chemospher. 69, 1446-1453.

Chen, Y., Senesi, N., Schnitzer, M. 1977. Information provide on humic substances by E4/E6 ratio. J. Soil Sci Am Soc. 41, 352-358.

Chen, Y., Senesi, N., Schnitzer, M. 1978. Chemical and physical characteristics of humic and fulvic 
acids extracted from soils of the Mediterranean region. Geoderma. 20, 87-104.

De Moraes, S.L., Rezende, M.O.O. 2008. Capillary Electrophoresis (CE): a Powerful tool to characterize humic acids (HA). J. Braz. Chem. Soc. 19,1 24-28.

d'Orlyé, F., Reiller, P. 2012. Contribution of capillary electrophoresis to an integrated vision of humic substances size and charge characterizations. J. Colloid Interf. Sci. 368, 231-240

Droussi, Z., D’Orazio, V., Hafidi, M., Ouatmane, A. 2009. Elemental and spectroscopic characterization of humic acids-like compounds during composting of olive mill by-products. J Hazard. Mater. $163,1289-1297$

Fernandez, J.M., Hockaday, W.C., Plaza, C., Polo, A., Hatcher, P.G. 2008. Effects of long-term soil amendment with sewage sludges on soil humic acids thermal and molecular properties. Chemospher. 73, 1838-1844.

Fuentes, M., Gonzalez-Gaitano, G., Garcia-Mina, J. M. 2006. The usefullness of UV-Vis and fluorescente spectroscopies to study the chemical nature of humic substances from soils and compost. Org. Geochem. 37, 1949-1959.

Gajalakshmi, S., Ramasamy, E.V., Abbasi, S,A. 2005. Composting-vermicomposting of leaf litter ensuing from the trees of mango (Mangifera indica). Biores. Technol. 96, 1057-1061.

Grube, M., Lin, J. G., Lee, P. H., Kokorevicha, S. 2006. Evaluation of sewage sludge-based compost by FTIR spectroscopy. Geoderma. 130, 324-333.

He, Z., Ohno, T., Olk, D.C., Wu, F. 2010. Capillary electrophoresis profiles and fluorophore components of humic acids Nebraska corn and Philippine rice soil. Geoderma. 156, 143-151.

Iglesias-Jimenez, E., Perez-Garcia, V. 1992. Determination of maturity indices for city refuses composts. Agr, Ecosyst. Environ. 38, 331-343.
Kaushik, P., Garg, V.K. 2004. Dynamic of biological and chemical parameters during vermicomposting of solid textile mill sludge mixed with cow dung and agricultural residues. Biores. Technol. 94, 203-209.

Ko, H. J., Kim, K. Y., Kim, H. T., Kim, C. N., Umeda, M. 2008. Evaluation of maturity parameters and heavy metal contents in composts made from animal manure. Waste Manage. 28, 813-820.

Kononova, M.M. 1982. Materia Orgánica del Suelo. Vilassar de Mar. Barcelona. España.

Koopal, L.K., Saito, T., Pinheiro, J. P., van Riemsdijk, W. H., 2005. Ion binding to natural organic matter: general considerations and the NICA-Donnan model. Colloid surface A: Physicochem Eng Aspects. $265,40-54$

Larchevêque, M., Ballini, C., Korboulewsky, N., Montes, N. 2006. The use of compost in afforestation of Mediterranean areas: effects on soil properties and young tree seedling. Sci Total Environ. 369, 220-230.

Larney, F.J., Hao, X. 2007. A review of composting as a management alternative for beef cattle feedlot manure in southern Alberta, Canada. Biores Technol. 98, 3221-3227.

Lasaridi, K., Protopapa, I., Kotsou, M., Pilidis, G., Manios, T., Kyriacou, A. 2006. Quality assessment of composts in the Greek market: The need for standards and quality asurance. J Environ Manage. 80, 58-65.

Lazcano, C., Goméz-Brandón, M., Domínguez, J. 2008. Comparison of the effectiveness of composting and vermicomposting for the biological stabilization of cattle manure. Chemosphere. 72, 1013-1019.

Lguirati, A., Ait Baddi, G., El Mousadik, A., Gilard, V., Revel, J. C., Hafidi, M. 2005 Analisys of humic acids from aerated and non-aerated urban landfill compost. Int Biodeter Biodegr. 56, 8-16. 
Lhadi, E.K., Tazi, H., Aylaj, M., Genevini, P.L., Adani, F. 2006. Organic matter evolution during co-composting of organic fraction of municipal waste and poultry manure. Biores Technol. 97, 2117-2123.

Loffredo, E., Berloco, M., Senesi, N. 2008. The role of humic fractions from soil and compost in controlling the growth in vitro of phytopathogenic and antagonistic soil-borne fungi. Ecotox Environ Safe. 69, 350-357.

Loffredo, E., Senesi, N. 2009. In vitro and in vivo assessment of the potential of compost and its humic acid fraction to protect ornamental plants from soil-borne pathogenic fungi. Sci Hort. 122, 432-439.

Machesky, M. 1993. Calorimetric acid-base titrations of aquatic and peat derived fulvic and humic acids. Environ Sci Technol. 27, 1182-1198.

Nederlof, M.M., van Riemsdijk, W.H., Koopal, L.K. 1994. Heterogeneity analysis for binding data using adapted smoothing spline techniques. Environ Sci Technol. 28, 1037-1047.

Pertusatti, J., Prado, A.G.S. 2007. Buffer capacity of humic acid: Thermodynamic approach. J Colloid Interf Sci. 314, 484-489.

Peuravouri, J., Lepane, V., Lehtonen, T., Pihlaja, K. 2004. Comparative study for separation of aquatic humic substances by capillary zone electrophoresis using uncoated, polymer coated and gel-filled capillaries. J Chromatogr A. 1023, 129-142.

Peuravuori, J., Lehtonen, T., Lepane, V., Pihlaj, K. 2005. Comparative study for differentiation of aquatic humic-type organic constituents by capillary zone electrophoresis using polyvinyl alcoholcoated capillary. Talanta. 67, 103-111.

Pietro, M., Castaldi, P. 2004. Thermal analysis for the evaluation of the organic matter ecvoluton during municipal solid waste aerobic composting process. Thermochim Acta. 413, 209-214.
Plaza, C., Nogales, R., Senesi, N., Benitez, E., Polo, A. 2008. Organic matter humification by vermicomposting of cattle manure alone and mixed with two-phase olive pomace. Biores Technol. 99, 5085-5089.

Plaza, C., Senesi, N., Brunetti, G., Mondelli, D. 2005. Co-composting of sludge from olive mill waste water mixed with tree cuttings. Compost Sci Util $13,3,217-226$.

Pognani, M., Barrena, R., Font, X., Adani, F., Scaglia, B., Sanchez, A. 2011. Evolution of organic matter in full-scale composting plant for the treatment of sewage sludge and biowaste by respiration techniques and pirolisis-GC/MS Biores Technol. 102, $4536-4543$

Pognani, M., Barrena, R., Font, X., Scaglia, B., Adani, F., Sanchez, A. 2010. Monitoring the organic matter proprieties in a combined anaerobic/aerobic full-scale municipal source-separated waste treatment plant. Biores Technol. 101, 6873-6877

Ponsá, S., Gea, T., Sanchez, A . 2010. The effect of storage and mechanical pretreatment on the biological stability of municipal solid waste. Waste Manage. 30, 441-445

Ritchie, J.D., Perdue, E.M. 2003. Proton-binding study of standard and references fulvic acids, humic acids, and natural organic matter. Geochim Cosmochimi Acta. 67, 85-96.

Roletto, E., Barberis, R., Consignlid, M., Jodice, R. 1985. Chemical parameters for evaluation of compost maturity. Biocycle March. 46-48

Romero, E., Plaza, C., Senesi, N., Nogales, R., Polo, A. 2007. Humic acids-like fractionin raw and vermicomposted winery and distillery waste. Geoderma. 139, 397-406

Sellami, F., Hachicha, S., Chtourou, M,, Medhioub, K., Ammar, E. 2008. Maturity assessment of composted olive mill waste using UV spectra and humification parameters. Biores Technol. 99, 6900-6907. 
Sellami, F., Hachicha, S., Chtourou, M., Medhioub, K., Ammar, E. 2007. Bioconversion of waste from the olive oil and confectionery industries: spectroscopy study of HA. Environ Technol. 28, 1285-1298.

Sen, B., Chandra, T.S. 2007. Chemolytic and solidstate spectroscopic evaluation of organic matter transformation during vermicomposting of sugar industry waste. Biores Technol. 98, 1680-1683.

Senesi, N. 1989. Composted materials as organic fertilizer. Sci Total Environ. 81, 521-542.

Senesi, N., Brunetti, G. 1996. Chemical and physicochemical parameters for quality evaluation of humic substances produced during composting. In: de Bertoldi M. et al. (eds). The Science of composting. Part 1. Blackie Academic \& Proffesional, Glasgow.

Senesi, N., Plaza, C., Brunetti, G., Polo, A. 2007. A comparative survey of recent results on humiclike fraction in organic amendments and effects on native soil humic substances. Soil Biol Biochem. 39, 1244-1262.

Sims, J.R., Haby, V.A. 1971. Simplified colorimetric determination of soil organic matter. Soil Sci. 112, 137-141.

Smidt, E., Tinter, J. 2007. Application of differential scanning calorimetry (DSC) to evaluate the quality of compost organic matter. Thermochim Acta, 459, 87-93.
Stevenson, F.J. 1982. Humus chemistry. Genesis, composition, reactants. John Wiley and Sons N. York.

Sutton, R., Sposito, G. 2005. Molecular structure in soil humic substances: the new view. Environ Sci Technol. 39, 9009-9015.

Tomati, U., Madejon, E., Galli, E., Capitán, D., Segre, A.L. 2001. Structural changes of humic acids during olive mill pomace composting. Compost Sci Util. 9, 2, 134-142.

Vanifatova, N.G., Zavarzina, A.G., Spivakov, B.Y. 2008. Potential of capillary zone electrophoresis for estimation of humate acid-base properties. J Chromatogr A. 1183, 186-191.

Velasco, M., Campitelli, P., Ceppi, S., Havel, J. 2004. Analysis of humic acid from compost of urban wastes and soil by fluorescence spectroscopy. Agriscientia XXI . 1, 31-38.

Wu, L., Ma, .L.Q., Martinez, G.A. 2000. Comparison of methods for evaluating stability and maturity of biosolids compost. Journal of Environ Qual. 27, 424-429.

Xiaowei, L., Meiyan, X., Jian, Y., Zhiding, H. 2011. Compositional and functional features of humic acid-like fraction from vermicomposting of sewage sludge and cow dung. Journal of Hazard Mater. $1185,740-748$ 
